\title{
Analysis of Patient Safety Management in Committee for Quality Improvement and Patient Safety at Sumbawa Hospital, West Nusa Tenggara
}

\author{
Evie Sulahyuningsih'), Didik Tamtomo'), Hermanu Joebagio3) \\ ${ }^{1)}$ Masters Program in Public Health, Universitas Sebelas Maret \\ ${ }^{2)}$ Department of Anatomy, Faculty of Medicine, Universitas Sebelas Maret \\ 3)Faculty of Teaching and Educational Sciences, Universitas Sebelas Maret
}

\begin{abstract}
Background: Patient safety is a crucial issue and a focus of policy standard in internationally accredited organizations. The specific committee responsible for quality improvement in patient safety is the committee for quality improvement and patient safety (PMKP). Incidence of malpractice often occurs but are not reported. It indicates that the committee has not worked according to required accreditation standard. This study aimed to analyze patient safety management with the committee for quality improvement and patient safety at Sumbawa Hospital, West Nusa Tenggara.

Subjects and Method: This was a qualitative study with phenomenology approach. Nine study participants were selected purposively, consisting of 3 committee members (chairperson, secretary, and patient safety sub-committee), 3 chiefs of ward (pediatrics, internal medicine, and surgery), and 4 nurses or midwives (pediatrics, surgery, ICU/ICCU, and obstetrics).

Results: The committee for quality improvement and patient safety has been established at Sumbawa Hospital, West Nusa Tenggara to meet the requirement of hospital accreditation standard. It aimed to improve the quality of services and to assure patient safety. However, its work has not meet the required standard. The lack of knowledge among involving parties, including hospital management, PMKP member, medical professionals was identified as one important obstacle for the implementation of patient safety management. This has led to the incidence of malpractice at the hospital, sub-standard quality of services and patient safety.

Conclusion: PMKP has been established at Sumbawa Hospital, West Nusa Tenggara. However, their work have not meet the required standard. The lack of knowledge among involving parties, including hospital management, PMKP, and health professional, has led to the incidence of malpractice at the hospital, sub-standard quality of services and patient safety.
\end{abstract}

Keyword: quality improvement, patient safety management, committee

\section{Correspondence:}

Evie Sulahyuningsih. Masters Program in Public Health, Sebelas Maret University, Jl. Ir. Sutami 36 A, Surakarta 57126, Central Java. Mobile: 087864104985.

\begin{tabular}{l}
\hline BACKGROUND \\
\hline Patient safety is a critical issue in hospitals \\
that are often published and internationa- \\
lized. Patient safety becomes the policy \\
standard in international accreditation \\
organizations (El-Jardali et al., 2011). The \\
Hospital Accreditation Committee (KARS) \\
has developed patient hospital safety \\
standards in the hospital patient safety \\
standard instrument to improve patient
\end{tabular}

care quality and ensure patient safety (Priyoto and Widyastuti, 2014).

The Committee that plays a role in patient safety is a quality improvement and patient safety committee (PMKP) that reaches out to all departments in the hospital. Implementation of the work program of the committee is not easy because it requires good coordination and communication between the heads of 
Journal of Health Policy and Management (2017), 2(2): 147-156

https://doi.org/10.26911/thejhpm.2017.02.02.06

fields/ medical division, nursing, medical support, administration, and others including head unit / department / service installation. The Patient Safety Committee is one of the sub-committees of PMKP that plays a role in patient safety management including programming and reporting, monitoring and evaluation, developing patient safety indicators, documenting, investigating and analyzing related patient safety incidents (KARS, 2017).

The implementation of patient safety management in hospitals plays a very important role in preventing or minimizing the occurrence of adverse patient safety incidents. Patient safety is the responsibility of all parties relating to health care providers. Stakeholders have a responsibility to ensure that no action is harmful to the patient (Kangasniemi et al., 2013). Patients also play a greater role in managing their health in order to support patient safety efforts (Bishop and Macdonald, 2014).

Factors contributing to the onset of KTDs in hospitals include the fact that communication about treatment and surgery is the most important that affects the patient safety culture (Smith et al., 2017). An analysis of 2,455 sentinel events reported to the organi- cation of the health accreditation commission showed that 70\% of the cases were the result of failure in communication (El-Jardali et al., 2011).

Joint Commission International (JCI) and World Health Organization (WHO) report that some countries have $70 \%$ of the treatment errors cases, even though JCI and WHO have issued "Nine Life-Saving Patient Safety Solutions" or 9 patient safety solutions. In fact, the patients' safety issues are still prevalent, including in Indonesia (JCI, 2017).

The issue of patient safety in Indonesia began to arise in 2000, followed by some first studies conducted in 15 hospitals with 4500 medical records. The results showed that the rate of KTD varies greatly, ie $8.0 \%$ to $98.2 \%$ for misdiagnosis and $4.1 \%$ to $91.6 \%$ for treatment errors. Since then, evidence of patient safety in Indonesia has spread, although there has been no national study to date (AranazAndrés et al., 2011).

The report reflects that patient safety management is poorly applied, so KTD is still happening. In response to this, Indonesia has established KKP-RS (Hospital Hospital Patient Committee) since 2005 by PERSI (Indonesian Hospital Association). Since 2006, patient safety and clinical risk management workshops are attended by nearly 1900 hospital staff (doctors, nurses, etc.) from +250 hospitals throughout Indonesia (Ministry of Health, 2015).

In 2008, the national hospital's accreditation body made patient safety the accreditation standard through the establishment of the PMKP committee. Law Number 44 of 2009 on Hospital and patient safety shall be carried out by the Hospital, and Ministry of Health regulation number 1691 of 2011 on patient safety (Ministry of Health, 2015). The majority (84\%) of healthcare professionals can stimulate action to improve patient safety culture (Zwijnenberg et al., 2016).

The report of patient safety incidents by province in 2008 showed that in DKI Jakarta province (37.9\%), Central Java (15.9\%), D.I. Yogyakarta (18.8\%), East Java (11.7\%), South Sumatra (6.9\%), West Java (2.8\%), Bali (1.4\%), Aceh (10.7\%) and South Sulawesi (0.7\%) (KKP-RS, 2008 in Keles et al., 2015). The most common case is a drug mistake that often leads to lawsuits and ends in court. Seeing the phenomenon, it is true that hospital patient safety program is very important and is an improvement of the quality program that has been 
implemented conservatively (Kemenkes, 2009).

The role of the management or the hospital's PMKP committee is crucial in patient safety management, since patient hospital safety incidents are expected at zero defect (o\% incidence rate). Implementation requires good coordination and communication between the head of the field / medical division, nursing, medical support, administration, and others including the head of unit / department / service installation (KARS, 2017).

Based on a preliminary survey at the Sumbawa Regional Public Hospital, the new PMKP committee was established in 2017. The national accreditation agency has established patient safety standards regarding the establishment of the PMKP committee since 2008. The implementation of patient safety management has not been maximal and is not in accordance with the established patient safety standard. Staff knowledge and awareness are still low, so there is no reporting and documentation of patient safety incidents.

The purpose of this study was to analyze patient safety management at PMKP committee in Sumbawa Hospital.

\section{SUBJECTS AND METHOD \\ 1. Study design}

This research was conducted at Sumbawa Regional Public Hospital, Sumbawa Regency, West Nusa Tenggara. The reason for the selection of this place, because the role of the PMKP committee, especially the patient's sub-safety has not been run in accordance with safety management standards. The study was conducted in November 2017.

This research is qualitative using an phenomenology approach that is approach which gives description, reflection, interpretation, and research mode that convey the essence of life experience of individual studied (Afiyanti and Rachmawati, 2014).

The phenomenology approach is an approach that provides descriptions, reflections, interpretations, and modes of research that convey the essence of the individual life experience studied (Afiyanti and Rachmawati, 2014).

\section{Participants}

Participants in this study were the committee of PMKP, head of space and nurse/ midwife in the inpatient ward of RSUD Sumbawa which fulfilled the research criteria. The selection of participants by purposive sampling technique is selected with consideration and certain objectives by means of participants selected (Sugiyono, 2015). The number of participants is 9, consisting of 3 committee managers (head, secretary, and patient safety sub-committee), 3 headroom (children, internal medicine, and surgery as well as secretary of the committee), and 4 nurses / midwives in-patient, surgery, icu / iccu, and midwifery).

\section{Data Collection Techniques and Analysis}

The data were collected with in-depth interviews, observations and document studies. Data analysis used thematic analysis. Braun and Clarke (2014) revealed that thematic analysis was a method for identifying, analyzing the theme, and meaning of a data in relation to a research question or providing a description of the data as a whole.

\section{Study Instrument}

The data collection instrument was the researcher. The data collection tools were questionnaires, interview guides, observation sheets (checklists), observation note sheets, document study notes, tape recorders, and cameras. 
Journal of Health Policy and Management (2017), 2(2): 147-156

https://doi.org/10.26911/thejhpm.2017.02.02.06

\section{RESULTS \\ 1. The role of the CTF committee in the patient safety management perspective}

The PMKP Committee was established in an effort to improve the quality of patient care and ensure patient safety. This committee is also to meet the standards of hospital accreditation that has activities with a very wide spectrum. One of the subcommittees responsible for the patient's health is the patient safety committee.

This sub-Committee plays a role in patient safety management including programming and reporting, monitoring and evaluation, developing patient safety indicators, documenting investigations and analyzes related to patient safety incidents. The program has been prepared by the committee, but its implementation still can not be implemented as a whole since the new committee is just formed.

Determination of SOPs related to patient safety programs should be established as a basis or standard in doing something. At hospital in Daerah Sumbawa, starting from the making of the documents to the printed form is the task of the working group of patient safety, where the team is at the same time a sub team of patient safety. This indicates that the implementation system of management has not been up to standard. This is due to the limited knowledge related to the role of PMKP committees in patient safety.

Socialization to each unit related to the role of PMKP committee should be done so that all officers, especially health personnel in order for them to know what the job description is, authority and responsibility of the committee. Some participants and officers in each unit do not know yet and do not understand the role of the PMKP committee, nor even know the existence of this committee in the hospital.
This is due to socialization related to the role of PMKP committee.

\section{The implementation of patient safety management}

The implementation of 6 SKPs in Sumbawa Regional Public Hospital has not run maximally yet. This is due to various constraints, namely limited knowledge and awareness of personal / officers and management or hospital and limited facilities and infrastructure in doing 6 SKP. Non-compliance in the implementation of six patient safety goals (SKP) increases patient safety incidents (IKP).

The events of IKP shall be reported by the concerned officer to the head of the unit responsible for the unit. The reporting report shall have its standard. In fact, so far the Regional Public Hospital of Sumbawa does not have an IKP-related reporting system. When the IKP does not report or report the head of the unit verbally, so there is no data or documents related to the number of incidents that occurred in the hospital.

Incidents related to IKP often occur in the hospital, but in the implementation of the reporting system found several obstacles, namely the understanding and awareness of the personal and the existence of blame culture / blame culture.

Patient safety education and training should be provided to all hospital personnel. Sumbawa District General Hospital has programmed it, it just has not been implemented to all officers or staff. The implementation wasn only at the head unit level.

\section{Outcome of the implementation of patient safety management}

Monitoring and evaluation was done as a follow up of the programs that have been conducted. In Sumbawa Regional General Hospital, the monitoring and evaluation related role of PMKP committee in patient 
safety management cannot be done. This is because the newly formed PMKP committee in the hospital and the implementation of the SKP is still in the socialization stage.

\section{DISCUSSION \\ 1. The role of QIPS committee in the perspective of patient safety management}

QIPS committee was formed to support the accreditation. The role is to improve the quality and safety of the patients. The workplan of the committee is to determine 6 SKP indicators and incident analysis. The hospital management system has not been properly implemented, thus impacting on the implementation of QIPS committee's role in patient safety management which has not been up to standard. The implementation of the work program can be properly done if the management, committee administrators, head unit, and officers or technical officers understand the role and work program of the QIPS committee. The most common practices in improving patient safety culture are goal setting and strong action planning for quality improvement, the implementation of patient safety initiatives and programs, and good survey administration methods (Campione and Famolaro, 2017).

The lack of understanding and the incompatibility of QIPS committee's role are due to a lack of information given by the government. Education and training related to the role of the committee need to be done so that committee members can understand and perform their roles which are in accordance with their duties, responsibilities and authorities.

Educational strategies and adherence to protocols, the development and implementation of simulation-based training programs are undertaken for the improvement of technical and nontechnical skills (Lee et al., 2014). The QIPS committee/team and also the person who is responsible of the data in the work unit should do the hospital data management training, namely collection, analysis, and improvement plan. In addition, in order to do a proper coordination and organizing by QIPS committees/teams, the management training of patient safety is needed. (KARS, 2017).

\section{The Implementation of Patient Safety Management}

In Sumbawa Hospital, patient safety management has not worked well. Management functions such as planning, organizing, actuating, and controlling (Gillies, 1994) on patient safety are still not implemented according to the standards.

The function of planning is as the basis implementation of other management functions. The patient's safety planning function at Sumbawa Hospital is included in the formulation of work programs about patient safety. The program includes the formulation of indicators, the preparation of activity guidelines, training and development programs, the socialization of quality indicators related to patient safety, and patient safety analysis. The work program that has been set certainly requires an approach strategy to be implemented in accordance with expectations, therefore, it can improve the quality and patient's safety culture.

The improvement of patient's safety culture through the implementation of routine cultural measurements with broad results of dissemination. There are action plans for improvement that include leadership support and the involvement from all levels of staff, and a variety of patient safety programs as well as education (Campione dan Famolaro, 2017). 
Journal of Health Policy and Management (2017), 2(2): 147-156

https://doi.org/10.26911/thejhpm.2017.02.02.06

Organizing function is a strategy in implementing the patient safety program. The impact of several strategies in improving the patient safety culture shows strong evidence that supports best practices in improving safety culture (Morello et al., 2013). The organizing in Sumbawa Hospital has not properly done. The allocation of resources, tasks arrangement, and procedures are still unclear. The management of QIPS committee is mostly unfamiliar with the duties, responsibilities, and authorities, they also do not understand about the organizational structure of the QIPS committee.

There are lacks of understanding, awareness, and behaviour in improving patient safety, therefore, the safety culture of patients in Sumbawa Hospital has not been implemented. In accordance with Social Cognitive Theory, environmental, personal, and behaviour are the factors of patient safety. Cognitive, emotional and behavioral aspects will affect the implementation of a patient safety culture. One of the intervention strategies related to patient safety is by implementing patient safety training (Bandura, 2001).

The implementation of training for managers and all officers/staff is essential in improving the understanding, therefore, the awareness of each role can be implemented according to patient safety standards.

Training intervention is useful in improving the perception, attitude and awareness of personnel toward safety culture, therefore, it decreases the number of adverse incidents and improve the safety of patient (Xie et al., 2017). The training conferences provide benefits for trainees in using unique perspectives to identify the susceptibility of system and develop innovative solutions (Smith et al., 2017).
The institution should be active in facilitating the transparency practice of adverse incidents, so that adverse incidents can be reported (Bell et al., 2015). In addition, organizational knowledge can be conducted through practice learning approaches, and government practices need to be aligned to the whole organization. The srategies are required in the leadership roles of the patient safety quality domains, interaction between the center and the leadership areas which affects the organization (Turner et al., 2014).

The patient safety culture that has not been implemented indicates that the organizing system is still deficient. This is an inhibiting factor in the implementation of patient safety management and it leads to the enhancement of patient safety incidents.

One of the ways to encourage a positive perspective is that the managers should create systems and environments which can help the nurses in improving their organizations. A management style that respects the role of nurses in patient safety and encourages the responsibility and control of patient safety by nurses lead to positive perceptions of patient safety (Mwachofi et al., 2011).

The actuating function is a set of established patient safety program. The role of QIPS committee for patient safety management is urgently needed. A leader must have the power to direct, implement, support and organize all activities, therefore, the entire civitas hospital will be motivated to implement the patient safety program.

Transformational leadership is highly important to improve the safety of patients and also to improve nurses' job satisfaction. Leaders or managers who involved in leadership actions can improve the empowerment of professional practices, 
therefore, it can improve the quality of the working environment and the safety of patients (Boamahet al., 2017). The managers are expected to improve the patient safety efforts because managers or the influencers can do more to support a patient's safety culture (Danielsson et al., 2017).

The controlling function is conducted to assess the extent to which the work program has been carried out in accordance with the patient safety standard. In Sumbawa Hospital, patient safety incidents are often occur, but the PSI (Patient Safety Incident) reports and documentation system has not been implemented. This results in the absence of data regarding the number and type of incidents. Without the reports and documentation, evaluation can not be done, therefore, there is no follow-up from PSI to improve the quality of service and patient safety.

General System Theory (GST) stated that the concept of subsystem is related to each part as causality. The implementation of patient safety program is a series of systems that affect each other. If the incident reports are not written, then the hospital will not have the data about the number of incidents, therefore, the monitoring and evaluation cannot be done. This will affect the quality of patient services and safety (Von Bertalanffy, 1956).

Blaming culture in PSI is one of the obstacles that often occur in the hospital. The fear of being blamed and being punished makes the employees/officers refuse to admit their mistakes.

Individuals should not be blamed for an error system in an incident. Instead of blaming the individual, analyzing the causes of errors and handling the problem together are the actions which have to be done (Stewart, 2017). Blaming may affect the quality of error reports. Leaders can teach the staff to investigate and to ask the negative outcomes for the patients without blaming, leaders should also cultivate the improvement of the working environment rather than give punishments to prevent Blame-Related Distress (Davidson et al., 2015).

System is the key in improving patient safety. Systems that encourage data input, data analysis, and feedback without the fear of punishment can lead to more error reports and they also form the processes that eliminate the consequences of errors (Radhakrishna, 2015).

\section{The Outcome of Patient Safety Management}

Monitoring and evaluation system is essential to evaluate the progress of a program. The monitoring and evaluation should be conducted periodically to find out the constraints that can be found during the process. Sumbawa Hospital has not conducted monitoring and evaluation which is related to the role of QIPS committee in patient safety management, therefore, the success of the patient safety program is unknown.

Attribution Theory can be applied in patient safety management to evaluate the success and failure of the system. Monitoring and evaluation of patient safety programs is essential. If the result is not as expected, then the management can develop a positive working environment to ensure the safety of the patient (Weiner, 1935).

In addition, the fishbone diagram proposed by Ishikawa can be applied in identifying the possible causes of patient safety problems. Factors identified include both external and internal factors of the hospital. The internal factors are team, duty, staff, patient, working environment, communication, management, and organization. While the external factors are 
everything that comes from outside the hospital such as government policy or politics, law and legislation, economic and socio-cultural (Tague, 2005).

Based on the description above, it can be concluded that the QIPS committee was established to support the accreditation, in which the role of the committee in patient safety management is the key in managing the quality improvement and patient safety program.

The implementation of patient safety which is not up to standard can increase the PSI. This is because the patient safety management is a series of interrelated systems that affect the quality of service and patient safety.

Monitoring and evaluation are conducted to evaluate the success and failure of the patient safety program. If the result is not as expected, then the management can develop a positive working environment to ensure the safety of the patient.

\section{REFERENCE \\ $\overline{\text { Afiyanti Y, Rachmawati IN (2014). Meto- }}$ dologi Penelitian Kualitatif Dalam Riset Keperawatan. Jakarta: PT Raja Grafindo Persada. \\ Aranaz-Andrés JM, Aibar-Remón C, Limón-Ramírez R, Amarilla A, Res- trepo FR, Urroz O, Larizgoitia I (2011). Prevalence of adverse events in the hospitals of five Latin American countries: Results of the "Iberoame- rican study of adverse events" (IBEAS). BMJ Quality and Safety, 20(12): 1043-1051. https://doi.org/- 10.1136/bmjqs.2011.051284.}

Bandura A (2001). Social Cognitive Theory: An Agentic Perspective. Annual Review of Psychology, 52(1): 1-26. https://doi.org/10.1146/annurev.psyc h.52.1.1
Bell SK, White AA, Yi JC, Yi-Frazier JP, Gallagher TH (2015). Transparency When Things Go Wrong: Physician Attitudes About Reporting Medical Errors to Patients, Peers, and Institutions. Journal of Patient Safety, 16. https://doi.org/10.1097/PTS.ooo0000000000153

Bishop AC, Macdonald M (2014). Patient Involvement in Patient Safety- A Qualitative Study of Nursing Staff and Patient Perceptions. J Patient Saf, 1-6.

Boamah SA, Spence-Laschinger HK, Wong C, Clarke S (2017). Effect of transformational leadership on job satisfaction and patient safety outcomes. Nursing Outlook, 1-10. https://doi.org/10.1016/j.outlook.2017.10.004.

Braun V, Clarke V (2014). Successful Qualitative Research. https://doi.org/9781847875815

Campione J, Famolaro T (2017). Promising Practices for Improving Hospital Patient Safety Culture. Joint Commission Journal on Quality and Patient Safety, (62). https://doi.org/10.1016/j.jcjq.2017.09.001.

Danielsson M, Nilsen P, Rutberg H, Årestedt K (2017). A National Study of Patient Safety Culture in Hospitals in Sweden, 1-6.

Davidson JE, Agan DL, Chakedis S, Skrobik Y (2015). Workplace blame and related concepts: An analysis of three case studies. Chest, 148(2): 543-549. https://doi.org/10.1378/chest.15-0332.

El-Jardali F, Dimassi H, Jamal D, Jaafar M, Hemadeh N (2011). Predictors and outcomes of patient safety culture in hospitals. BMC Health Services Research, 11(1): 45. https://doi.org/10.1186/1472-6963-11-45

JCI (2017). JCI Accreditation Standards for Hospitals, 6th Edition. Joint Commis- 
sion International. Retrieved January 3, 2018, from https://www.jointcommissioninternational.org/jci-accreditation-standards-for-hospitals-6thedition/.

Kangasniemi M, Vaismoradi M, Jasper M (2013). Ethical issues in patient safety: Implications for nursing management, 20(8): 904-916.

KARS (2017). Efektif 1 Januari 2018, 421.

Keles A (2015). Analisis pelaksanaan standar sasaran keselamatan pasien di Unit Gawat Darurat RSUD Dr. Sam Ratulangi Tondano sesuai dengan akreditasi rumah sakit versi 2012. Jikmu, 5(3): 250-259.

Kemenkes (2009). Standar Perlindungan Pasien Perlu Disosialisasikan ke Seluruh Rumah Sakit. Retrieved January 4, 2018, from http://www.depkes.go.id/article/view/407/standarperlindungan-pasien-perlu-disosialisasikan-ke-seluruh-rumah-sakit.html.

Kemenkes (2015). Pedoman Pelaporan Insiden Keselamatan Pasien; Kemenkes 2015.pdf. Retrieved January 3, 2018, from https://www.scribd.com/document/364248247/PedomanPelaporan-Insiden-KeselamatanPasien-Kemenkes-2015-pdf

Lee A, Mills PD, Neily J, Hemphill RR (2014). Root Cause Analysis of Serious Adverse Events Among Older Patients in the Veterans Health Administration. The Joint Commission Journal on Quality and Patient Safety, 40(6): 253-262. https://doi.org/10.1016/S1553-7250(14)40034-5.

Morello RT, Lowthian JA, Barker AL, McGinnes R, Dunt D, Brand C (2013). Strategies for improving patient safety culture in hospitals: a systematic review. BMJ Quality \& Safety, 22(1), 11-18. https://doi.org/10.1136/bmjq-
S-2011-000582.

Mwachofi A, Walston SL, Al-Omar BA (2011). Factors affecting nurses' perceptions of patient safety. International Journal of Health Care Quality Assurance, 24(4): 274-283. https://doi.org/10.1108/09526861111125589.

Priyoto, Widyastuti T (2014). Kebutuhan Dasar Keselamatan Pasien. Yogyakarta: Graha Ilmu.

Radhakrishna S (2015). Culture of blame in the National Health Service; Consequences and solutions. British Journal of Anaesthesia, 115(5): 653-655. https://doi.org/10.1093/bja/aev152

Smith A, Hatoun J, Moses J (2017). Increasing Trainee Reporting of Adverse Events With Monthly Trainee-Directed Review of Adverse Events. Academic Pediatrics, 17(8): 902-906. https://doi.org/10.1016/j.acap.2017.0 1.004

Smith SA, Yount N, Sorra J (2017). Exploring relationships between hospital patient safety culture and Consumer Reports safety scores. BMC Health Services Research, 17(1): 1-10. https://doi.org/10.1186/s12913-017-20786.

Stewart KR (2017). SBAR, Communication, and Patient Safety: An Integrated Literature Review. MEDSURG Nursing, 26(5): 297-305. Sugiyono (2015). Metode Penelitian Pendidikan Pendekatan Kualitatif, Kuantitatif, dan R \& D. Bandung: Alfabeta.

Tague NR (2005). Fishbone Diagram (Ishikawa) - Cause \& Effect Diagram. The Quality Toolbox. Retrieved from http://asq.org/learn-about-quality/cause-analysis-tools/overview/fishbone.html.

Turner S, Higginson J, Oborne CA, Thomas RE, Ramsay AIG, Fulop NJ (2014). Codifying knowledge to improve 
Journal of Health Policy and Management (2017), 2(2): 147-156

https://doi.org/10.26911/thejhpm.2017.02.02.06

patient safety: A qualitative study of practice-based interventions. Social Science and Medicine, 113: 169-176. https://doi.org/10.1016/j.socscimed.2 014.05.031.

Von-Bertalanffy L (1956). General System Theory. General Systems: Yearbook for the Society for the Advancement of General Systems Theory.

Weiner (1935). Attribution Theory (Weiner) - Learning Theories. Retrieved January 3 , 2018, from https://www.learning-theories.com/weiners-attributiontheory.html.

Xie J, fei, Ding, S. qing, Zhong, Z. qing,
Zeng, S. nan, Qin, C. xiang, Yi, Q. feng, Zhou J (2017). A safety culture training program enhanced the perceptions of patient safety culture of nurse managers. Nurse Education in Practice, 27: 128-133. https://doi.org/10.1016/j.nepr.2017.08.003.

Zwijnenberg NC, Hendriks M, Hoogervorst-Schilp J, Wagner C (2016). Healthcare professionals' views on feedback of a patient safety culture assessment. BMC Health Services Research, 16(1): 1-11. https://doi.org/10.1186/s12913-016-1404-8. 